\title{
Spectacle, architecture and place at the Nuremberg Party Rallies: projecting a Nazi vision of past, present and future
}

\author{
Joshua Hagen and Robert Ostergren \\ Department of Geography, Marshall University, \\ Department of Geography, University of Wisconsin-Madison
}

\begin{abstract}
Nuremberg, perhaps more than any other place, stands central among iconic images of Nazi Germany. The Nazi regime went to great lengths to inscribe its basic tenets into Nuremberg's urban landscape. While many are already familiar with the role Nuremberg played as the site of the annual Nazi Party Rallies, few realize that the Nazi building programme in Nuremberg placed great emphasis on redesigning the city's historical centre in addition to developing the extensive rally grounds on the city's edge. This article explores the architectural form, performative function and motivating ideologies associated with these extensive building programmes in Nuremberg and, rather than seeing them as two separate projects, highlights the intimate connections between the construction of the rally grounds on the city's edge and the concurrent redesign of the city's historical centre. Although seemingly irreconcilable in terms of style and scale, these efforts to build and rebuild in Nuremberg were actually seen as complementing elements in the regime's programme to create and project images of historical greatness, current political legitimacy and promises of future grandeur.
\end{abstract}

\section{Introduction}

To city in Nazi Germany was as important symbolically as Nuremberg, the official 1 site of the Nazi Party Rallies. The rallies, held in Nuremberg on two occasions during the 1920s and on an annual basis throughout much of the 1930s, were a series of gigantic, theatrically staged celebrations of Nazi unity, fanaticism and power. Extensively covered in the media, and vividly captured in Leni Riefenstahl's classic film, Triumph of the will, the rallies captured the attention of the world, leaving both Germans and non-Germans alike suspended in a nervous state of fascination, admiration and fear. Even today, decades after the cataclysmic defeat of Nazi Germany, the city of Nuremberg continues to live on in the memory of Germans 'as the symbolic place of National Socialist rule. ${ }^{1}$

Geographers exploring the linkages between spectacle, identity and place have often approached landscapes as texts to be read. ${ }^{2}$ More recently, scholars have emphasized 
the ways in which these landscapes serve as a type of stage for human action. Whereas the metaphor of the text implies a rather passive role for landscape, the idea of landscape as a stage and an emphasis on the role of performance recognize a greater degree of dynamism and interaction between people and place. ${ }^{3}$ Indeed, as Nuala Johnson recently argued: 'This notion of landscape as theatre could be further extended, not solely as the backdrop in which the action takes place but as actively constituting the action. The stage acts more than as the context for the performance; it is the performance itself. ${ }^{4}$

The Nuremberg Party Rallies were political spectacles designed to generate public support for the Nazi regime through the performance of an annual ritual, characterized by a high degree of mass pageantry. To be effective, spectacles of this kind are often situated in landscapes endowed with a history capable of evoking a particularly powerful sense of national pride and belonging. Nuremberg served well this requirement. The city had a long, romantic history and contained many historic features of architectural and cultural importance. Nuremberg was thus in many ways already a national symbol. What remained was to convert it into a participatory landscape, in which spectacle and architecture might combine to legitimate and glorify the regime, enhance the personal charisma of Adolf Hitler and imbue amongst the masses a strong sense of National Socialist community and purpose. $^{5}$

The theatrical aspects of the rallies depended greatly on their venue. In this sense, the rally agenda coincided with another preoccupation of the National Socialists and their leader: the idea that German cities typically lacked the kind of symbolic spaces and architecture necessary to galvanize a strong sense of community and purpose. In Mein $K a m p f$, Hitler lamented that the inevitable result of this deficiency was 'a desolation whose practical effect is the total indifference of the big-city dweller to the destiny of his city'. ${ }^{6}$ The Nazi regime, therefore, chose to embark on an ambitious building programme that would refashion German cities with new monumental spaces and structures intended to focus Germans on the glory of their country as well as on the goals and values of National Socialism. Architecture, in particular, was seen as a powerful expression of national greatness. ${ }^{7}$

This article explores the interactions of spectacle, architecture and place embodied in the Nuremberg Party Rallies. We focus first on the official rally grounds located just outside the city. Here we examine the ways in which a carefully calculated use of space and architecture effectively created a world of ritual ceremony and rhetoric capable of generating an almost phantasmal sense of mass fascination and awe among participants and observers. Our analysis, however, also leads us into the city centre, since the rallies were anything but confined to the rally grounds on the city's edge. As the 'City of the Party Rallies', Nuremberg's historic centre was a fundamental but often-overlooked part of the celebrations. In particular, the Nazi building programme sought to restore, improve and preserve the city's central environs simultaneously to remind the nation of the city's historic greatness and to enhance the city's suitability as a stirring venue for rally activities and ceremonies. 
In the end we hope to emphasize the connectedness between what might be called the 'old' Nuremberg of the Middle Ages and the 'new' Nuremberg of the 1930s. The authorities, both party and civic, apparently saw no inconsistency in the goals of restoring, cleansing and preserving a historic cityscape in the town centre while simultaneously constructing a thoroughly modern and forward-looking rally site outside the city. The seeming incongruity of the two endeavours was reconciled by a desire to build a sense of German pride that connected the new and glorious vision of a National Socialist future with a romantically inspiring symbol of Germany's national past. We also wish to emphasize the interdependence between these carefully contrived landscapes and the emotional response of the multitudes that witnessed or performed the spectacles staged upon or within them. In other words, what makes the Nuremberg rallies perhaps unique is their unprecedented capacity to fuse spectacle, architecture and space into a single participatory experience.

\section{The Rally Grounds}

Nuremberg was not the first city to host the Party Rallies. The first rally took place in Munich, the birthplace of the party, in 1923. Because Hitler was banned from public speaking in Bavaria following his failed putsch, the second rally in 1926 took place in Weimar. After the Bavarian ban was lifted in 1927, Nuremberg came under consideration as a site for the third and possibly future rallies, but the choice was hardly a foregone conclusion. For one thing, Nuremberg had never been a stronghold of Nazi political support. The city was actually considered a 'red' stronghold of the Social Democrats. Moreover, the municipal government initially seemed lukewarm to the idea of turning over the city's public buildings and grounds to the Nazi celebrations. On the other hand, the city was an attractive site because of its symbolic association with German history, art and culture stemming from its days as an imperial city during the Middle Ages; because of its relatively accessible location in central Germany; and because it possessed public facilities and grounds capable of providing adequate meeting space. In the end, Nuremberg was chosen. ${ }^{8}$ Successful rallies were held there in 1927 and 1929; and in 1933 Hitler declared at the opening of the city's third rally that Nuremberg would henceforth be the permanent locale. The rallies were then held in Nuremberg each September until suspended by the outbreak of war in 1939.

The early rallies of 1927 and 1929 were marked by improvisation, not only in the planning of scheduled events but also in the use of the city's spaces and public facilities. ${ }^{9}$ Beginning with the 1933 rally, however, a far more elaborate staging of events and venues evolved. The rallies soon developed into carefully orchestrated and predictable affairs that lasted eight full days, attended by as many as a quarter of a million people. The ritual began on the first day with the Führer's dramatic arrival in Nuremberg, followed by a day of march-pasts and cultural events. Succeeding days were devoted exclusively to the Labour Service, the ideal of community, political leadership, the Hitler Youth and the Storm Troopers. The final day belonged entirely to the military. ${ }^{10}$ As the events became more elaborated and standardized, so too did the 
determination to stage the largest and most important of them in a monumental complex of newly constructed arenas, stadia and meeting halls befitting a Reich that was destined to last a thousand years.

The 'Rally Grounds' complex that eventually took shape was located just south-east of the city. This area had already been set aside in the late nineteenth century as a pleasure and recreation ground. The foci of the area's pre-rally development were the Dutzendteich Lake, with its lakeside café, and the nearby Luitpold Grove. The latter was a landscaped pleasure park originally developed as the venue for the 1906 Bavarian Jubilee Exhibition. In 1928 a memorial to the dead of the First World War was constructed on the north-east side of the park. The Nazis, who used the park during the 1927 and 1929 rallies, viewed this open space and particularly its war memorial, which recalled the martyrdom of Germany's First World War soldiers and the humiliation of the Versailles Peace, as a particularly emotive setting for rally events. The extensive recreational area to the south-east of the city also contained a zoo, a number of sporting fields, a public swimming pool and a municipal stadium with a capacity of $50000 .^{11}$

Incorporating all of these existing sites and facilities and more, the official Rally Grounds covered an immense area of 16.5 square kilometres. A special public corporation (Zweckverband Reichsparteitag Nürnberg) created in 1935 partnered the city of Nuremberg, the state of Bavaria, the Reich and the Nazi Party to oversee the development of the grounds. ${ }^{12}$ With the intense backing of Hitler, the project enjoyed priority status for financial and material resources from the beginning. Between rallies, the grounds became a place of feverish construction, earning the sobriquet 'the world's largest building site'. In all there were six major components to the complex, some of which were never completed (see Figure 1).

The first of these was the Luitpold Grove and its First World War necropolis, which became the complex's most hallowed ceremonial ground. This facility was completely reworked for the rallies. The former landscaped pleasure park was callously levelled, flanked by massive stone grandstands and transformed into the Luitpold Arena. The resulting formalized space served as the stage for one of the most moving moments of the rally schedule. On the seventh day of the proceedings, the massed ranks of more than 150000 SA and SS Storm Troopers filled the floor of the arena. Hitler and his entourage then passed solemnly between the ranks along a granite path leading straight to the steps of the war memorial, where the Führer would pay his respects to the nation's and the party's martyred dead. Connected to the Luitpold Arena was the Luitpold Hall, a meeting hall with a capacity of 16000 redesigned and enlarged from a structure built for the 1906 Bavarian Jubilee Exhibition. ${ }^{13}$

A second, and equally pivotal, ceremonial space was the Zeppelin Field. Built between 1934 and 1936, this squareish, stadium-like facility was a radical transformation of what had once been an amateur sports field named after Count Zeppelin, the German airship pioneer, who used it briefly for experimental flights in 1909. The new facility's most impressive feature was the Tribune. This grandiose stone structure, which ran the full length of one side of the field, was the work of the young architect Albert Speer, whom Hitler also commissioned to oversee a master plan for the Rally Grounds complex. Speer's Tribune took the form of a long grandstand-like structure, flanked at 


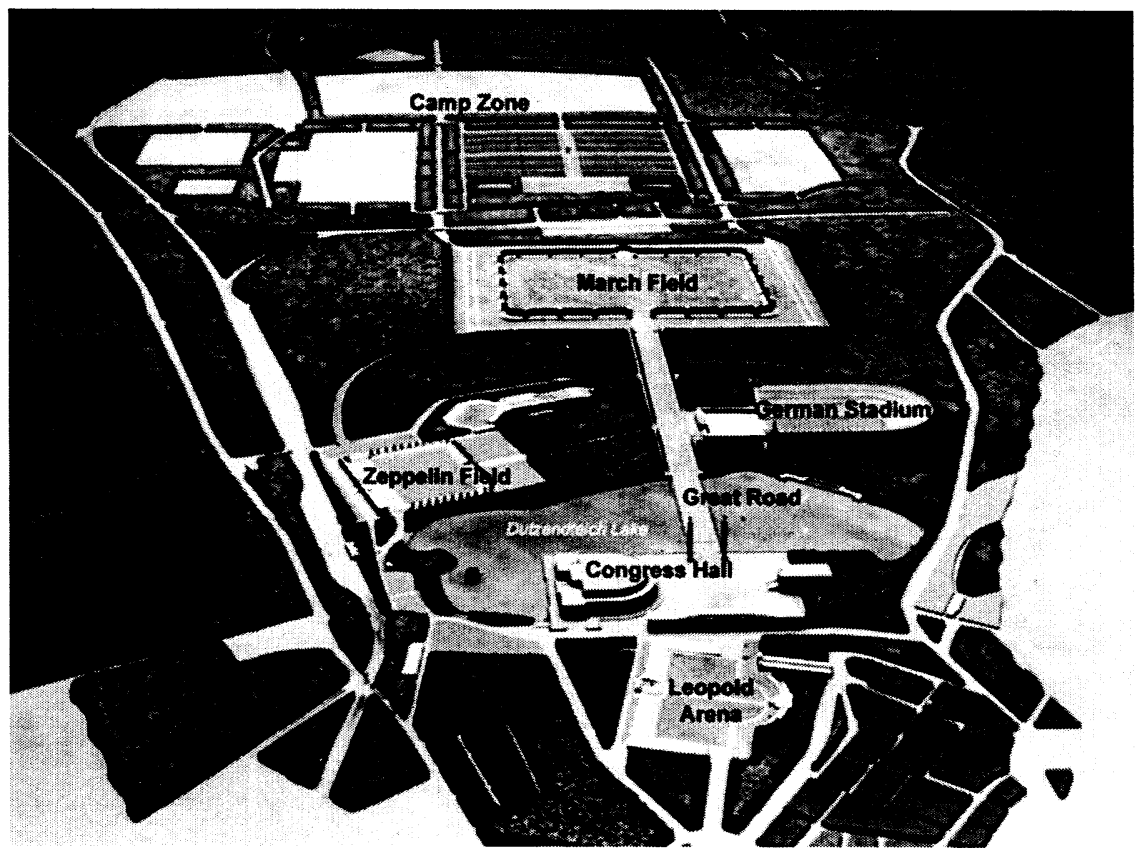

FIGURE 1 'World's largest building site': model of the Nazi Party Rally Grounds, 1936. (Courtesy Stadtarchiv Nürnberg.)

each end with massive 'book-end' pylons, and dignified by a colonnaded screen behind the seating, topped by a giant swastika set in an oak leaf wreath. A small, squareish podium, or Führer's rostrum, jutting out from a raised platform at the centre of the structure, allowed Hitler to review march-bys of Labour Service battalions and youth groups, and military demonstrations staged by the armed forces (see Figure 2).

Two other massive outdoor facilities were planned and begun, although neither was ever completed due to the outbreak of war. One was the March Field (Märzfeld), the construction of which was prompted in part by the realization that the Zeppelin Field was probably too small to hold the enlarged rallies of the future. This new arena, which was begun in 1938 on what had been a parade and exercise area for the army, was intended to hold half a million. The other was the German Stadium, which was to be a truly colossal affair, with a seating capacity of 405000 - far more than any other sports stadium in the world. Indeed, Hitler believed that the completed stadium would become the permanent site for the Olympic Games, which by his decree would henceforth be known as the Germanic World Festival. The immense horseshoe-shaped stadium was to be built entirely of stone (enough to severely strain the granite-cutting capacity of the Reich for many years) and magnificently fronted at its open end by a propylaeum and columned courtyard. ${ }^{14}$ The structure was also to be adorned on high with gigantic spread-winged eagles, Grecian urns, and 25-metre high equestrian statues. The cornerstone was laid in 1937, but little of the stadium was ever completed. 


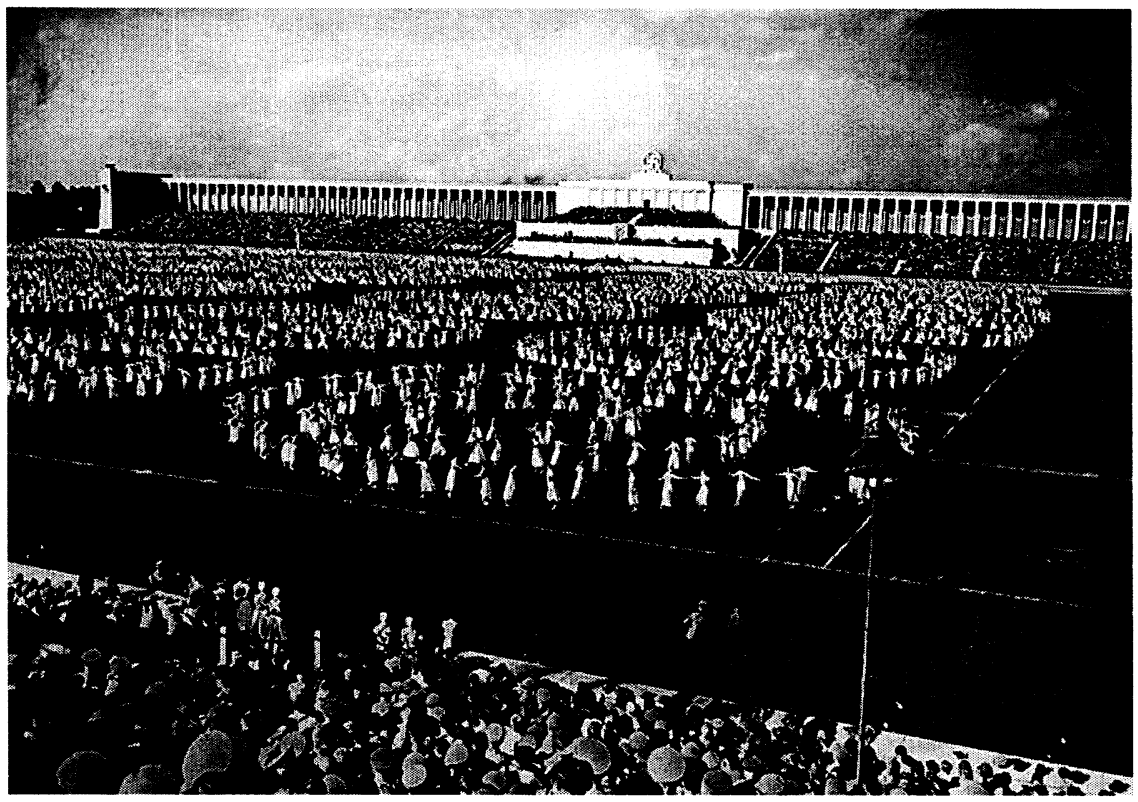

FIGURE 2 Space, spectacle and architecture: young women performing on the Zeppelin Field, 1938. (Courtesy Stadtarchiv Nürnberg.)

The other mega structure of the Rally Grounds was the Congress Hall. Designed by Ludwig and Franz Ruff in 1934, it was an immense auditorium designed to hold 50000 Party Congress delegates on its main floor, with room for another 2400 on its main stage. This building was situated picturesquely along the north shore of the Dutzendteich Lake. Construction was begun in 1935. Most of the building's outer shell was completed, but the interior was never finished. The structure is today the largest monumental building, along with the Zeppelin Field Tribune, to survive the Nazi era.

A host of other structures and facilities rounded out the Rally Grounds ensemble. These included a multi-winged barracks for the SS, built between 1937 and 1939 on the western edge of the grounds; the old municipal stadium, which continued to be used for parades and Hitler Youth events; a number of permanent camps on the southern and eastern peripheries that housed participants belonging to various organized groups, such as the SA, the SS, the Labour Service, the Hitler Youth, the Strength through Joy and the Young Women's organizations. The largest of these camps, known as the Langwasser, was spacious enough to accommodate more than 200000 people. In addition, two railway stations served the grounds, one near the camps and the other just to the east of the Zeppelin Field. A power station and water tower provided the camps with basic services.

The rallies were political spectacle extraordinaire. They drew heavily on a tradition of national festivities and public celebrations in Germany dating back to the mid-nineteenth century, but were consciously designed to employ every conceivable tool that could transport crowds into a state in which they subconsciously surrendered themselves en masse to the high drama and mystical euphoria of the moment. The result was indeed 
thought of as a Gesamtkunstwerk or 'total work of art'. ${ }^{15}$ To accomplish this the proceedings relied heavily on the stirring and anticipatory effects of martial music, trumpeted fanfares and thundering drums; on the visually exhilarating effects of massed blocks of uniformed marching men and women, phalanxes of flags and standards, and the surreal effects cast by thousands of flickering torches; and on the ecstatic effects of spellbindingly bombastic oratory and mass prolamations of undying loyalty.

One of the most spectacular examples of the highly choreographed proceedings took place in the Zeppelin Field. On the evening of the fifth day, the so-called 'day of the political leaders', the review field, which held as many as 100000 , and the surrounding stands, which held as many as 150000 more, were filled to capacity. As darkness fell anticipation ran high among the closely packed, torch-lit crowd. At a precise moment, spotlights illuminated Hitler's entrance to the field. As the Führer then strode across the field to mount the podium in front of the Tribune, 150 powerful searchlights around the perimeter of the field suddenly shot their long beams into the sky to envelope the proceedings in a ghostly 'cathedral of ice'. As Hitler prepared to harangue the crowd from his podium, excitement culminated amongst the assembled multitude with the exhilarating sight of tens of thousands of swastika flags and gleaming silver standards rushing forward in waves through the crowds, rousing the faithful into a sort of 'psuedo-sacred' fervour. ${ }^{16}$ The evening ended with the mass singing of the national anthem. This meticulously orchestrated emotional scene, artfully caught on film by Leni Riefenstahl and shown around the world, best exemplified the spellbinding and almost sacral atmosphere that characterized the rallies. ${ }^{17}$

To be ultimately successful, however, all of this required a perfect venue - just the right use of space and architecture. Careful attention to the use of space and spatial layout therefore loomed large in the design of all rally facilities. Hitler himself had strong views on the utility of space for the manipulation of a crowd's attention and mood. ${ }^{18}$ Rectangular spaces were deemed most effective, especially when they could be precisely defined on all sides by surrounding stands and stages, and seemingly isolated from the rest of the world by encircling displays of flags, banners and statuary, or - as in the case of the night rallies in the Zeppelin Field - by walls of light set against the dark sky. Clear lines of sight and direction were also important, as demonstrated by the layout of the 'granite path' that bisected the Luitpold Arena as it led to the steps of the War Memorial, or in the focal position of the Führer's rostrum at the centre of the Zeppelin Field Tribune and at the end of a main axis emanating from the entrance in the middle of the stands directly across the way. Size was also important. Rally facilities needed very large capacities so that the crowds in the stands along with the standing or marching participants massed on the field or auditorium floor could create an impression of immense human strength and solidarity. Thus, impressive as the mass ceremonies in the Luitpold Arena and Zeppelin Field may have been, an immediate need was felt for even larger facilities, such as the March Field and German Stadium.

The spatial layout of the entire grounds was also the subject of meticulous planning. A master plan, replete with a scale model mockup, was in place by $1935 .{ }^{19}$ A central axis or 'Great Road' ran for two kilometres in a north-westerly direction from the centre of Hitler's reviewing stand on the March Field to a great square just outside the 
Congress Hall. Designed to be 80 metres wide and paved with 60000 gigantic square slabs of granite, the Great Road created a grand processional way capable of conveying great columns of parading troops and rally goers. Once completed in 1939, the Great Road strictly aligned with the newer facilities - the March Field, the German Stadium, the Congress Hall and the various residence camps. The older facilities, whose location and orientation could not be changed, related somewhat awkwardly, but not at angles that placed them at great variance to the thrust of the axis. In a rather obvious attempt to link the Rally Grounds to the 'historic' greatness of the host city, the Great Road aligned directly with Nuremberg's old imperial castle, which dominated the old city's distant skyline. ${ }^{20}$

Equally important was the use of architecture. Hitler considered himself an aficionado of architectural history and technique; he often imagined himself a master builder, and dreamed of leaving a lasting physical imprint on German cities and landscapes. He understood the power of monumental building and spent countless hours fussing over architectural plans of various projects, among which the Rally Grounds held special importance. ${ }^{21}$ The designs of rally buildings and arenas had to satisfy multiple goals. Their primary purpose was to undergird the ritual spectacle of the various rally events; but these edifices were also meant to impress and instruct in the sense that the heroic ideals and scale of the Nazi movement should be evident in their form and style. They were also built to endure as an eternal testament to the power and grandeur of the Third Reich.

In Nazi Germany, the need to impress and instruct was an imperative that usually translated architecturally into gigantism. Speer classified the buildings for the Rally Grounds as 'assembly architecture', the purpose of which was to awe and inspire masses of people. ${ }^{22}$ Structures were therefore designed to overwhelm the senses by their sheer size. The plan for the German Stadium, for example, was so immense that spectators in the upper stands would have been hard pressed to observe the action on the field below without the aid of field glasses. The entrance pylons, portals and galleries of all of the facilities were typically far larger than life-the better to diminish those who passed through them. Thus, the vast lobbies that were to run beneath the seats of the German Stadium were designed to tower, cathedral-like, over the spaces they enclosed, while immense columns, pylons, statuary, emblems and symbols adorned the exteriors of stadia and buildings alike. The monumental dimensions of the Rally Grounds structures were a simple but effective means of impressing on the masses the extraordinary largeness and all-embracing character of National Socialist life.

Although Nazi architecture is, in general, noted for its lack of any consistent theory or style, the so-called Fübrerbauten - the projects personally commissioned and supervised by Hitler, which include Speer's designs for the Party Rally Grounds reflect Hitler's taste for neo-classical forms. ${ }^{23}$ Speer's design for the Zeppelin Field Tribune bears clear similarities to the Pergamon Altar of Hellenistic Greece, just as the German Stadium resembles the stadium of Herodes Atticus in Athens. ${ }^{24}$ There are also rather obvious similarities between the Colosseum in Rome and the Congress Hall, the design of which underwent changes inspired by Hitler's 1938 visit to Rome. ${ }^{25}$ Hitler and his architects were clearly attracted to the idea of using the architectural forms of a 
heroic classical past, particularly those of ancient Greece, as a means of legitimizing and grounding their vision of the present and future. In fact, however, the work done by Speer on the Rally Grounds went beyond the standard neo-classical mould, for his buildings also incorporated a certain modern abstract formalism derived from the 1920s. Many of the buildings thus were noteworthy for their employment of cubic mass, emphasis on right angles, great flat surfaces and solid angular decoration. ${ }^{26}$ The end result was a sort of abstract or modernized neo-classicism that managed to seem heroic, solid and forward-looking all at the same time - an illusion that was highly compatible with the political style of the Nazis, who so often strived to bring together carefully selected attributes of the old and the new (see Figure 3).

The final imperative was the command to endure. In his memoirs, Albert Speer reports that 'Hitler liked to say that the purpose of his building was to transmit his time and its spirit to posterity', adding: 'Ultimately, all that remained to remind men of the great epochs of history was their monumental architecture. ${ }^{27}$ Speer produced two recommendations that Hitler strongly endorsed. First, monumental buildings should feature time-honoured and natural materials that express a 'bridge of tradition' to future generations, rather than modern and anonymous materials. Second, monumental structures should be built to last so that, after thousands of years, a set of aesthetically acceptable ruins might remain, like those of the Greeks and Romans, as a testament to future generations. Consequently, the buildings of the Rally Grounds utilized ideologically acceptable and permanent materials like granite and marble whenever possible. However unintentionally, this also allowed at least some construction to

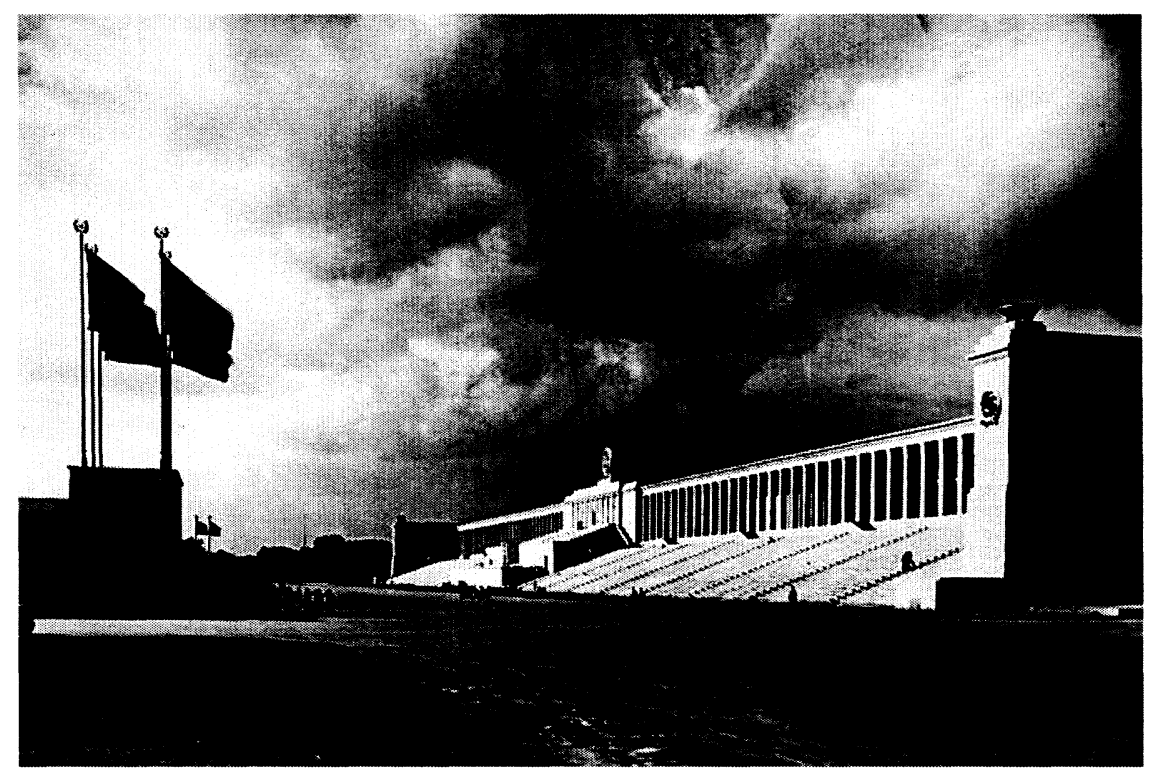

FIGURE 3 Abstract neo-classicism: the Zeppelin Field Tribune, c. 1937. Rally Grounds building were designed to impress, instruct, and endure. (Courtesy Stadtarchiv Nürnberg.) 
continue during the war years, as iron, steel and concrete became increasingly reserved for weapons production. ${ }^{28}$

The spectacle of the rallies thus unfolded, in part, within an ensemble of buildings and stadia designed both spatially and architecturally to enhance the involvement of rally participants and observers, to heighten the propaganda value of the rallies, and to leave a cold but permanent record in stone that would impress and instruct long after its builders were gone. The grounds were intended to become a sacred place - a site of cult-like celebration of strength and unity under National Socialism. In the words of regime spokesperson Otto Dietrich, speaking at the 1935 rally, 'This sacred site of the Party Rally Grounds with its unique concepts of architecture and use of space will be the highest symbol of National Socialist life and National Socialist culture, in it the unique style of German National Socialism will find its strongest expression. ${ }^{29}$

\section{The city}

In 1937 Nazi Germany's flagship art and architectural journal lavishly featured the new rally buildings as 'a monument of pride'. ${ }^{30}$ Given the high visibility afforded to the rallies by the regime's propaganda apparatus and the monumental nature of its architecture, it is not surprising that scholars have remained largely fixated on the Rally Grounds. Yet this narrow focus overlooks another component of the Nazi building programme that developed within Nuremberg's medieval walls in parallel with the new rally structures. Nuremberg was chosen as the location for the annual rallies partially because of its historical symbolism. The city's historic centre accordingly became an additional focal point for rally activities. In many ways, Nuremberg's historic centre served as an extension of the official rally grounds. And like the existing facilities at the Luitpold Arena or the Zeppelin Field, Nuremberg's historic squares, buildings and fortifications also required systematic reworking to reinforce the regime's political objectives. As planning and construction proceeded on the Rally Grounds, local party officials with the support of the national leadership aggressively launched a broad campaign to restore, preserve and improve Nuremberg's historic centre. The preservation campaign within Nuremberg's medieval walls was intended both to create a 'monument of pride' that would remind the nation of its past greatness and, like the new Rally Grounds, to signal the onset of a new and glorious age.

Although scholars have produced countless volumes analysing the urban planning policies and architectural styles favoured by the Nazi dictatorship, historical preservation has only recently emerged as a subject of interest. ${ }^{31}$ Reflecting this relative inattention paid to historical preservation, those who have explored the structures and symbolism of the rallies have tended to minimize the role of projects undertaken in Nuremberg's historic centre in creating an appropriate atmosphere for the rallies. Yet Nuremberg's historic centre was not a mere footnote to the massive spectacles on the Rally Grounds, but rather a constituent element in efforts to project and legitimize the Nazi regime's authority and legitimacy.

Nazi party officials embarked on a purposeful program to adapt Nuremberg's centre to a specific vision of history that would buttress the Nazi Party's political authority and 
its self-image as chief steward and pinnacle of German cultural and historical greatness. These efforts, led by Mayor Willy Liebel, were implemented by a small cadre of professional architects, preservationists and urban planners sympathetic to the regime's apparent commitment to preserving and restoring Germany's historical monuments. According to municipal preservationist Julius Lincke:

The reawakening of the German spirit has also reawakened the sense of German history everywhere. The remaining monuments to the existence and achievements of the German Volk, that had often sunken down to mere sites for a few summer tourists, have again become relics of the German Volk, for whose preservation everything must be done. ${ }^{32}$

In general, historical preservation in Nuremberg focused on three main themes. The first involved the restoration of historical structures, while the second focused on removing the 'building sins' of previous generations in an attempt to 'cleanse', 'purify' or otherwise aesthetically improve Nuremberg's historical image. 'Building sins' in this context usually referred to commercial buildings featuring modernist designs built in the late nineteenth and early twentieth centuries. ${ }^{33}$ Thirdly, preservation projects served to symbolize the Nazi Party's desired close connections with specific aspects of German medieval history. Although wide-ranging, these three themes helped reframe the past and present so that the Nazi Party under Hitler's leadership appeared as an inevitable historical culmination that would reconcile the German nation's cultural greatness with modernity and save the nation from racial and cultural degeneration.

Indeed, Mayor Liebel declared that 'the National Socialist city administration considers it as one of its most important tasks, to preserve the countless beauties of the old town and to free it from the defacements that it was partially exposed to in recent decades'. ${ }^{34}$ In order to demonstrate the party's commitment to this cause, Liebel ordered work to begin immediately on the 'restoration of architectural and artistic monuments threatened by decay, the purification of disturbing advertising and architectural disfigurements from the image of the old town, and the renovation of the old town'. 35

Given the dual importance of Nuremberg's main market square, as both the city's historical centre and site of several parades and activities during the annual rallies, local leaders decided to focus their initial efforts here. They began by renaming the square, originally called the Hauptmarkt, to Adolf-Hitler-Platz, but it was soon evident that they would not be satisfied with mere semantic changes. During late 1933 and early 1934, more substantive measures were undertaken to have a redesigned and improved Adolf-Hitler-Platz complete for the 1934 rallies. The centrepiece of the effort was the renovation of the Telegraph Building. Heinrich Höhn, a staff member of the German National Museum in Nuremberg, singled out this neo-gothic building, built in the 1870s, as an 'unbearable foreign body' that disturbed the square's medieval charm. ${ }^{36}$ Although cost considerations prevented its complete demolition, the Telegraph Building received a dramatic facelift (see Figure 4). The building's new simplified façade and pitched roof aimed to complement neighboring structures and create a more orderly aesthetic, while new anti-Semitic murals added to the façade provided an unmistakable message. In addition to targeting modern architecture, officials worked to realign windows and 

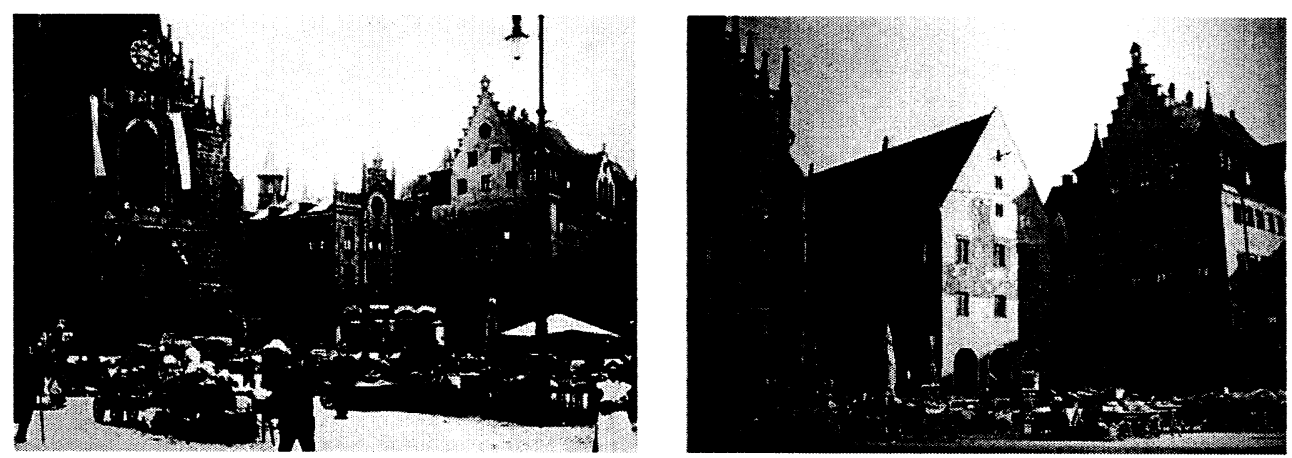

FIGURE 4 Historic preservation: House at Schildgasse 3, before and after renovation. (Courtesy Stadtarchiv Nürnberg.)

doors to harmonize the façades of buildings surrounding the square to conform to Nazi visual and ideological preferences. ${ }^{37}$

While the municipal administration concentrated on reframing Nuremberg's main square, the Bavarian president, Ludwig Siebert, and the Zweckverband financed the restoration of Nuremberg's imperial castle under the justification that it 'served the representative purposes of the state'. ${ }^{38}$ The castle, set at the north-western corner of the city's medieval fortifications, represented a potent symbol of medieval Germany's political and cultural greatness. Although much of its historic exterior remained intact, the interior had undergone significant modifications during the nineteenth century. Like the redesigned Adolf-Hitler-platz, restoration work inside the castle aimed for a 'thorough cleansing' of nineteenth century additions. The restorations strived for a rather simple, modest and orderly appearance intended to revive the castle's 'pure and unadulterated state'. ${ }^{39}$ The overall effect was to return the castle to its 'original monumental character and its powerful dignity' ${ }^{40}$ Later projects converted portions of the castle complex into an immense youth hostel with facilities for Hitler Youth leaders. The local administration hoped that the newly renovated hostel would immerse youths in the experience of the party rallies, optimistically proclaiming that 'thousands of German boys and girls will pass through it [the hostel] and take something of the spirit of greatness that prevails in it into their future life'. ${ }^{41}$

Nuremberg also conducted a 'cleansing' of its medieval fortifications. Local officials ordered vegetation stripped from the ramparts, refuse cleared, dilapidated sections of wall repaired and new footpaths laid out along the moats and trenches to create unobstructed views of Nuremberg's military heritage. ${ }^{42}$ The extensive restoration work on the castle and fortifications simultaneously demonstrated the regime's dedication to preserving historical monuments, accentuated the martial aspects of Nuremberg's historical architecture and integrated these medieval relics into an orderly and disciplined urban landscape.

Most other municipal historic buildings also underwent some degree of restoration during the Nazi period, including the town hall, the Holy Spirit Hospital and many 
of the town's churches. ${ }^{43}$ Although the Nazi Party had limited legal authority over the rights of property owners, local officials were able to pressure many homeowners into making aesthetic changes. Historic preservation efforts focused on giving homes and businesses an 'Old German' look by exposing half-timbering, as seen in Figure 5, as well as removing obtrusive signs of commerce and modern architectural forms like flat roofs, as illustrated in Figure 6. Referring to the latter structure, a local administrative report celebrated how 'one of the ugliest homes in the old town has today become one of the most beautiful'. ${ }^{44}$ By 1941, the administration claimed that municipal funds were partially responsible for the restoration of approximately 400 buildings. ${ }^{45}$

Although local officials used strong rhetoric when describing all preservation projects, their criticisms of Nuremberg's Jewish synagogue were especially virulent. Like other structures targeted for removal, the synagogue was built in a late nineteenth century historicist style, making it doubly objectionable to Nazi ideologues. Walter Brugmann, a local architectural consultant, had already identified this 'Moorish-style' synagogue as a 'building sin' in 1934 . $^{46}$ The building's perceived 'foreign' architectural style was compounded by its seemingly disproportionate size. Brugmann suggested a new porch as a partial remedy, but officials chose a more radical solution. In Mayor Liebel's view the synagogue was the worst building sin of past decades. ... A
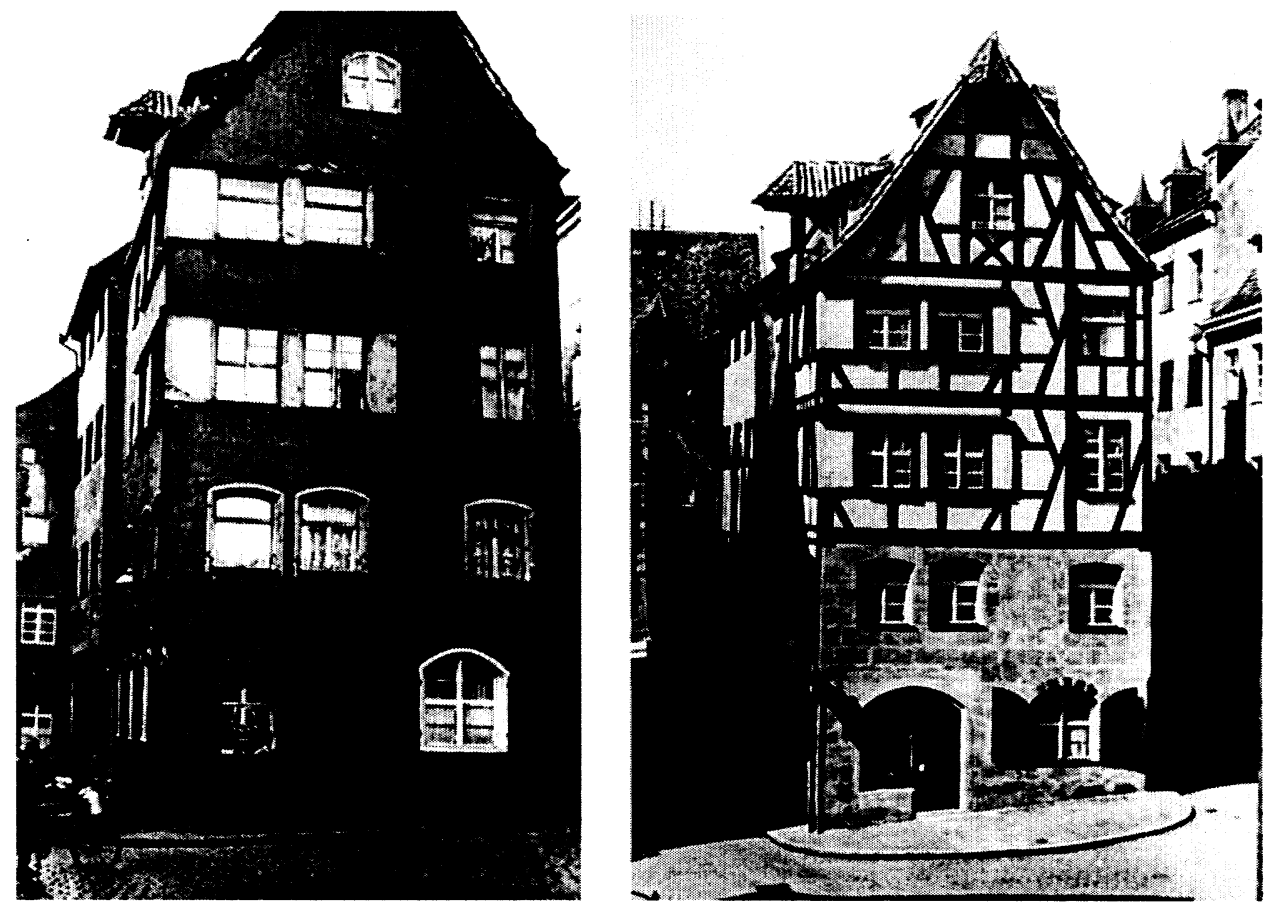

FIGURE 5 Improving the aesthetics of Nuremberg's historic centre: the Telegraph Building on Adolf Hitler Square, before and after renovation. (Courtesy Stadtarchiv Nürnberg.) 

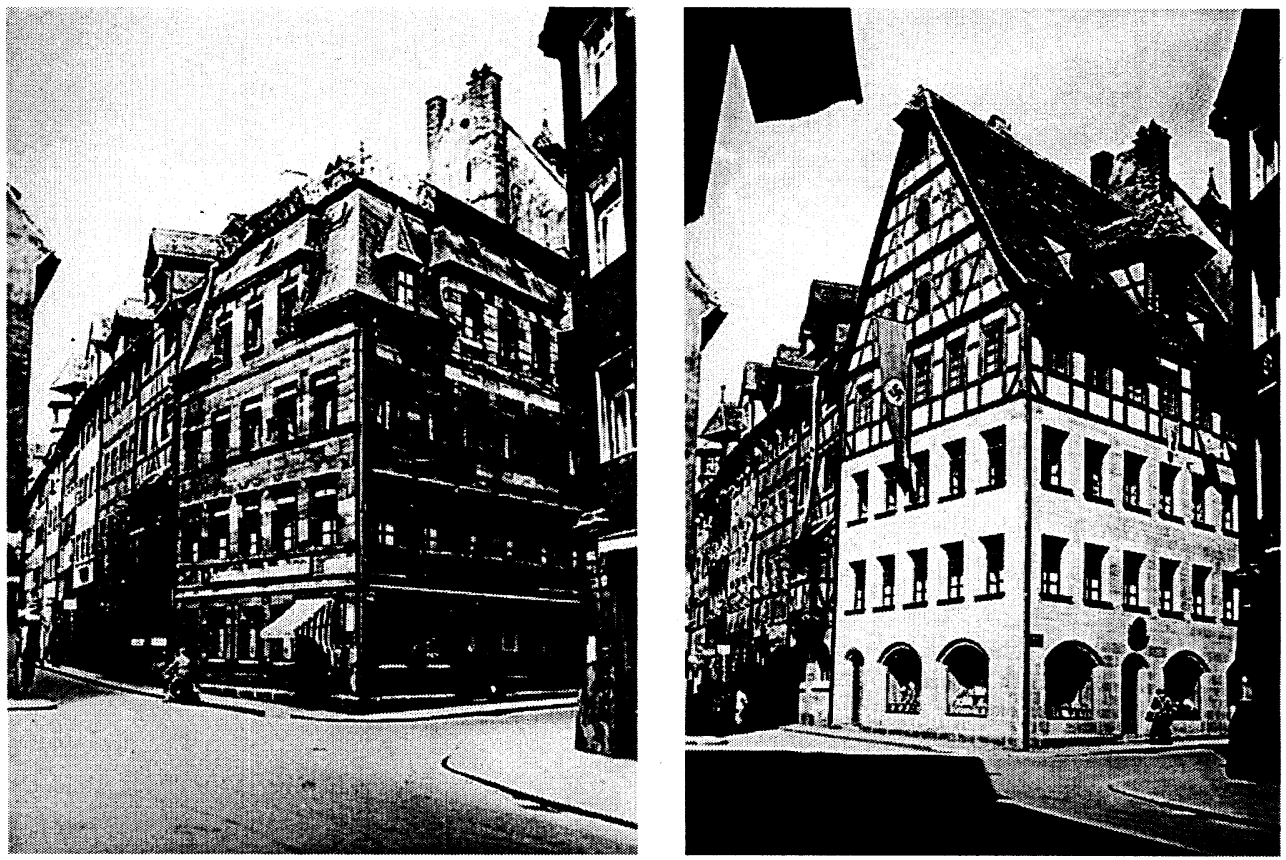

FIGURE 6 'Ugly' to 'beautiful': building on Ebnersgasse, before and after renovation. (Courtesy Stadtarchiv Nürnberg.)

settlement can only be reached through the complete removal of the synagogue. ${ }^{47}$ This 'foreign' building simply could not be reconciled with the 'Old German' image that local authorities endeavored to create. Armed with additional authority under the German Urban Renewal Law of 1937, Liebel completed the quasi-legal demolition of the synagogue shortly before the 1938 rallies began.

The Nazi building programme in Nuremberg's historic centre clearly intended to do more than just preserve historical architecture. It intersected in practice, rhetoric and goals with several basic tenets of Nazi ideology. First, the programme allowed the regime to demonstrate its support for preserving Germany's historical treasures, a goal with significant support among middle- and upper-class Germans. Preserving historical structures, especially those that dated to the Middle Ages, also connected the Nazi Third Reich with the perceived golden age of the Holy Roman Empire. To suggest this narrative, officials and preservationists attacked, in both rhetoric and practice, the material reminders of the period separating this golden past from the glorious present and future. By erasing the physical traces of this perceived downfall from the urban landscape a closer symbolic connection between medieval and Nazi Germany was created. The monumental nature of Nuremberg's urban fabric could thus represent the ideals of a traditional and cohesive community that coincided with Nazi calls for order, obedience and sacrifice. 'Nuremberg is the best preserved large city of the German Middle Ages,' art historian Friedrich Kriegbaum proclaimed. 
'Like hardly any other city, it is a grandiose self-portrayal of urban communal will in built form. 48

Finally, the use of biological metaphors in urban planning and preservation discourse reflected the regime's obsession with race. The programme to 'cleanse' Nuremberg's urban landscape of undue 'foreign' and commercial influences buttressed efforts to construct a racially pure nation. Germany's urban areas, like the nation itself, were viewed as threatened by foreign contaminants that had to be purged before Germany could reach its full potential. Looking back at the first years of the campaign, Brugmann noted with satisfaction that the 'city wall and ditches, the castle, the churches, the patrician and burgher homes were preserved in a perfectly professional manner and the alleys of old Nuremberg were decisively cleansed of excessive "commercialism".,49 While such themes were common in preservation and urban planning throughout Nazi Germany, Nuremberg's role as the site of the annual rallies added a special impetus and visibility to these efforts. As Brugmann took pains to emphasize, 'Nuremberg, fully conscious of this high distinction and honour, endeavours to give this new purpose an adequate frame by preserving and restoring the matchless beauty of its ancient scenery, by erecting new buildings, widening its streets, and by making other improvements. 50

\section{The 'old' and the 'new' Nuremberg}

We have so far reviewed the general course of the Nazi building programme both within Nuremberg's medieval walls and on the rally grounds located a short distance outside. The latter foresaw the construction of mammoth, modernized neo-classical structures, while the other focused on reworking relatively small details thought to contrast with Nuremberg's medieval heritage. Although seemingly irreconcilable in style, form and scale, these two projects were seen at the time as complementary. Viewing them in isolation provides only a partial and somewhat misleading view of Nuremberg's practical and symbolic role in Nazi Germany. These were not separate projects, but intimately intertwined as necessary elements of the regime's programme to create and project images of historical greatness, current political legitimacy and promises of future grandeur.

Friedrich Bock, a local library director, succinctly laid out this historical trajectory in his 1938 book Nuremberg: from the city of the Imperial Diets to the city of the Party Rallies. Bock constructed a narrative that painted medieval Nuremberg in glowing terms. This golden age was, however, followed by a period of neglect and cultural decline, especially during the nineteenth and early twentieth century. The Nazi seizure of power in 1933 marked a rebirth. 'The Third Reich has again brought great honour to the city,' Bock explained; 'it has again become, like during the height of the Middle Ages, one of the capitals of the Reich and, as in the proud imperial times, its name will be named together with the leaders of the Reich. ${ }^{51}$ For Bock, the Rally Grounds and improvements to the city centre symbolized Nuremberg's renewal and rejuvenation. 'In this way it is possible', Bock reasoned, 'to organically connect the old city of the Imperial Diets with the new city of the Party Rallies through the centuries. ${ }^{52}$ Indeed, 
after the annexation of Austria in 1938, Hitler ordered the crown jewels and regalia of the old Holy Roman Empire returned from Vienna to Nuremberg for permanent display. ${ }^{53}$ Nuremberg thus signified a resurrection of past national greatness under the leadership of the Nazi Party.

Carl Sabo's book developed these same connections between the city's past and present: 'For centuries Nuremberg as city of the gleaming Imperial Diets of the German emperors and kings stood in the centre of German history. With the designation as the city of the party rallies by the Führer, Nuremberg is today placed anew in the centre of German happenings. The gates of the city will be stone witnesses to these new glory days for the future. ${ }^{54}$ Introducing the book, Mayor Liebel hoped visitors, whether during the rallies or some other time of year, would feel this same impression. 'What of a visit to Nuremberg makes the deepest expression', Liebel explained, 'is the inner connection between the venerated past and the living and proud present. 55

Party officials made a special effort to reinforce this message for young Germans. Gottlieb Schwemmer, a government building official, authored an easy-reading political history for young Germans. After a cursory overview of Nuremberg's early history, Schwemmer described the nineteenth century as a period of cultural decline triggered by capitalism. The city's recent resurgence under Nazi leadership was gradually correcting these past mistakes. 'The city, that remained true to the symbols of the old empire as no other', Schwemmer argued, 'is also above all others determined to have the greatest monuments in its enchanted setting, on which the reflection of the coming epoch already rests. ${ }^{56}$ Through the combination of its old medieval centre and the new rally complex, Nuremberg would become an eternal symbol of German, and more specifically Nazi, achievements.

Another book, by Werner Dittschlag, made a similar point for German girls. Dittschlag began by comparing the tale of Sleeping Beauty with Nuremberg. Like a fairy-tale princess, Nuremberg had originally been a beautiful, vibrant city but was forced to endure an anguished slumber during the nineteenth century. Once Hitler woke Nuremberg, 'the old spirit of heroic deeds and loyalty returned within its walls. ... Nuremberg is once again a "centre point of the Reich", the Third Reich. ${ }^{57}$ The book details the role of women and girls in the rallies, and concludes by describing the massive structures planned for future rallies. Beyond the pomp of rally activities, these new structures and Nuremberg's medieval centre were destined to form an impressive new whole. As Dittschlag explained: 'Every German girl and every German boy will burn with desire to see the old and the new Nuremberg. ${ }^{58}$ Connections between these two Nurembergs were necessary to legitimate Nazism as the natural heir to Germany's proud history. A girls' magazine produced by the party visually encapsulated this message for its readers (see Figure 7). The cover features an eagle, long a symbol of Germany, surveying past and current symbols of German greatness. A drawing of the Zeppelin Field fills the foreground, while the silhouette of Nuremberg's castle and fortifications provides a shadowy backdrop.

Schwemmer had been keen to point out to his readers that the entire rally complex 'served as a counterbalance to the distant imperial castle which welcomes one into 


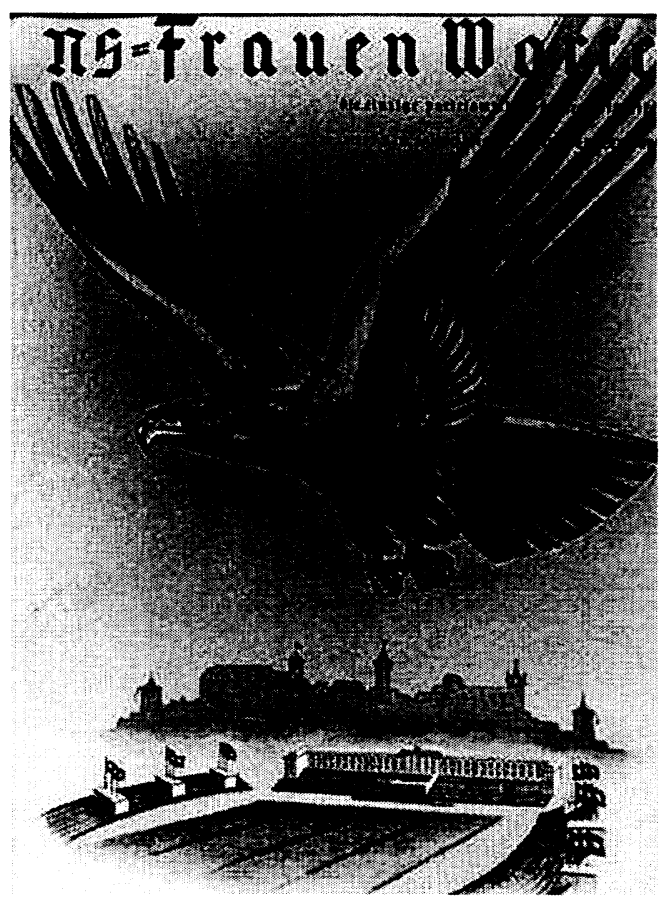

FIGURE 7 Connecting the two Nurembergs: cover of the girls' magazine NS-Frauen Warte, September 1939

Nuremberg's landscape image'. ${ }^{59}$ But efforts to forge connections between the rallies and Nuremberg's medieval past often went beyond mere verbal assertions. As we have seen, the Great Road, the broad central axis of the rally grounds, was purposely aligned with Nuremberg's imperial castle several kilometres to the north. The cover of a special issue of Die neue Linie, featuring the 1938 party rallies, offers a simplified representation of this relationship (see Figure 8). Indeed, connecting the rally grounds with the symbols of medieval Nuremberg was central to the iconography of the rallies. The official poster from the 1937 rallies, for example, juxtaposed Nuremberg's castle with searchlights from the rally grounds (see Figure 9).

The performative nature of the rallies also worked to highlight the conceptual message inherent in the Nazi building programme in Nuremberg. In many ways, the most dramatic performances of the rallies featured enormous parades of the various party organizations. It is no coincidence that many of these parade routes actually connected Nuremberg's imperial castle, Adolf-Hitler-Platz and the new Rally Grounds. These repeated spectacles of mass parades symbolically and literally constructed linkages between the medieval Holy Roman Empire and Hitler's Third Reich (see Figures 10 and 11). This trajectory was further enshrined in Leni Riefenstahl's groundbreaking film of the 1934 rallies, Triumph of the will. The film's opening sequences couple footage of Hitler's triumphal entry into old Nuremberg with lingering 


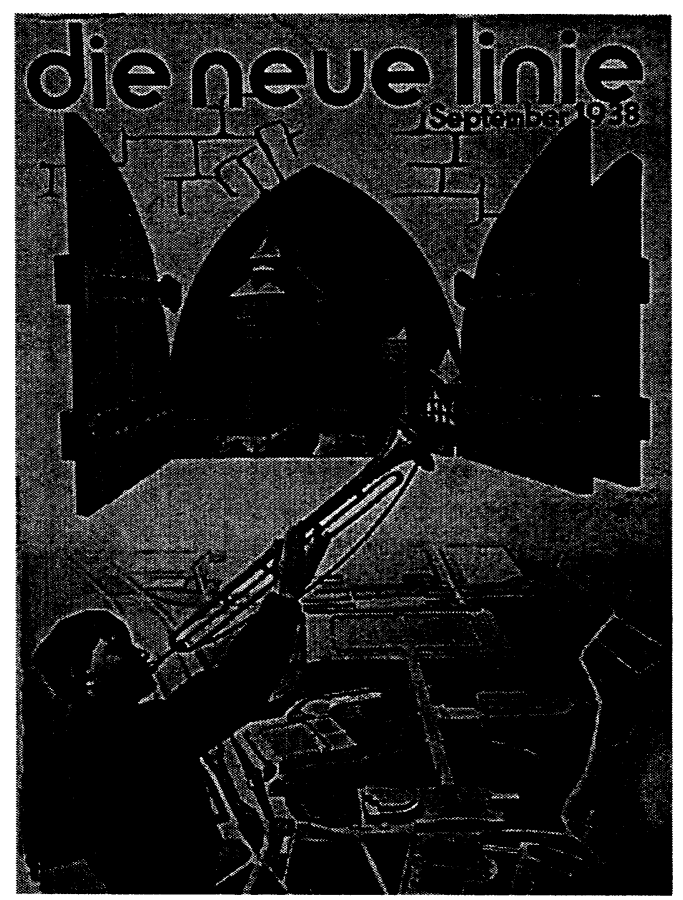

FIGURE 8 Juxtaposition of Rally Grounds and castle: cover of the magazine Die neue Linie, September 1938

shots of Nuremberg's historic buildings. Another long scene toward the end of Triumph complements coverage of Hitler reviewing a parade from the Adolf-Hitler-Platz with lavish views of old Nuremberg's streetscapes.

The Nazi building programme reworked Nuremberg's historical centre to represent, convey and historicize the Nazi movement and its ideology. Together with the massive new structures planned for the rallies, Nuremberg's historical centre helped portray the Nazi regime as the culmination of past historical greatness and the redeemer of a truly German national culture. There were certainly other places where the Nazi leaders planned to redesign cities around mammoth new structures, most famously their plans completely to redesign Berlin into the capital, Germania. There were also numerous programmes to preserve historical buildings, especially in smaller towns like Rothenburg. Nuremberg, in comparison, was the only place where the regime aggressively pursued both objectives. While other scholars have minimized or ignored attempts to establish links between the 'old' and the 'new' Nuremberg, these connections constituted integral components in the Nazi Party's efforts to reframe political and historical discourse. ${ }^{60}$ It seemed only fitting that, as one popular guidebook declared of Nuremberg, 'the old stronghold of the German imperial idea of the Middle Ages is today the stronghold of the new Reich'. ${ }^{61}$ 


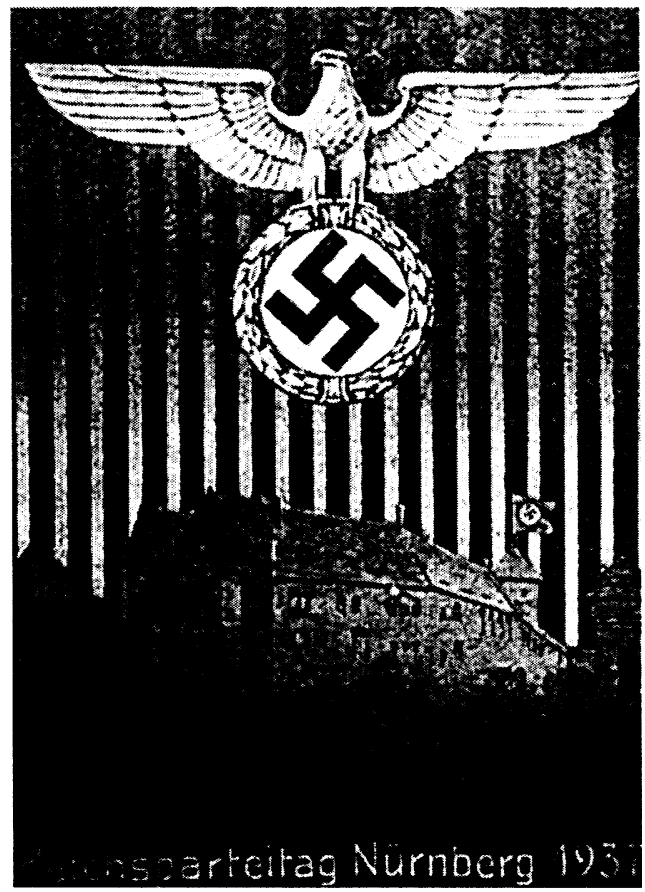

FIGURE 9 Official poster for the 1937 rally, combining elements of the 'old' and 'new' Nuremberg. (Courtesy Dokumentationszentrum Reichsparteitagsgelände).

\section{Conclusion}

While numerous rulers, governments and political movements have constructed grandiose monuments and staged lavish ceremonies, few such efforts can rival the impact of the Nuremberg Party Rallies. The rallies awed millions of contemporary Germans, as well as countless foreign observers. Indeed, Riefenstahl's Triumph of the will won awards in Germany, Fascist Italy and even the Grand Prize at the Paris International Film Festival in 1937. And even 60 years after the collapse of Hitler's Reich, these images of Nazi unity and power continue to fascinate. Yet, given the repeated use of politicized monuments and spectacles by numerous regimes throughout history, the reasons why the Nuremberg rallies in particular should have such a lasting legacy remain somewhat obscure. Many contemporary observers and later scholars credited the sheer size of the rallies. While the rallies were certainly massive, we believe that a greater awareness of the calculated use of place, space and architecture can lead to a more nuanced understanding of the intense emotional response generated by the rallies and the reasons the rallies achieved nearly iconographic status for later generations.

In studying the role of spectacles in forging national identity, Kong and Yeoh have argued: 'Spectacle may be designed to create an impact through the use of fear (thus, a 


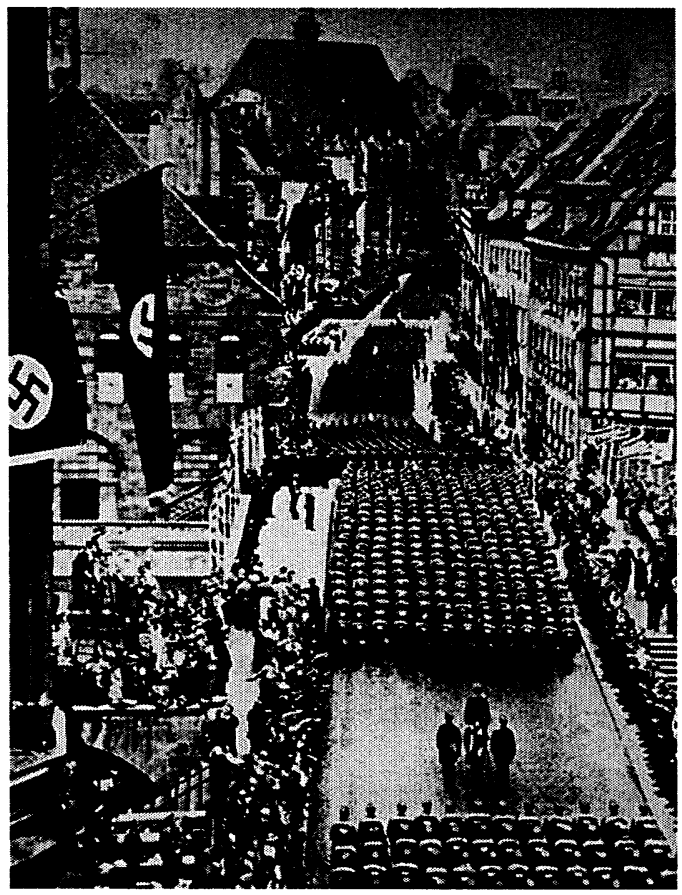

FIGURE 10 Marching through the streets of Nuremberg, 1934. The imperial castle is visible at the top of the hill. (Courtesy Stadtarchiv Nürnberg.)

punitive strategy) or the use of awe and wonder (a celebratory strategy). ${ }^{62}$ We would argue that part of the reason the spectacle of the Nuremberg rallies had such a resounding impact was because they effectively employed both of these strategies. The historical character of old Nuremberg lent itself well to celebrating Germany's past greatness, while the colossal structures of the new Nuremberg created an atmosphere of coercion and power. Unlike the ceremonies accompanying the Olympics (almost purely celebratory) or the military parades staged in communist dictatorships like North Korea (almost purely punitive), the Nuremberg rallies were able simultaneously to fascinate, awe and intimidate.

The principal reason the rallies were able to achieve this dual effect stems from the design and use of the rally's architectural spaces. While numerous geographers have written about the role of monuments and architecture in political and cultural discourse, the structures of the Nuremberg rallies differed significantly from most other monuments like the Sacré Cour basilica in Paris or Rome's Vittorio Emanuele II monument. ${ }^{63}$ Although developing in quite different contexts, these and most other monuments tend to be structures that politicians and their audiences generally gathered in front of, around or occasionally on. In this sense, these monuments functioned in a manner similar to stage scenery in a traditional theatre. In contrast, both in Nuremberg's medieval centre and on the Rally Grounds themselves, planners sought to create spaces 


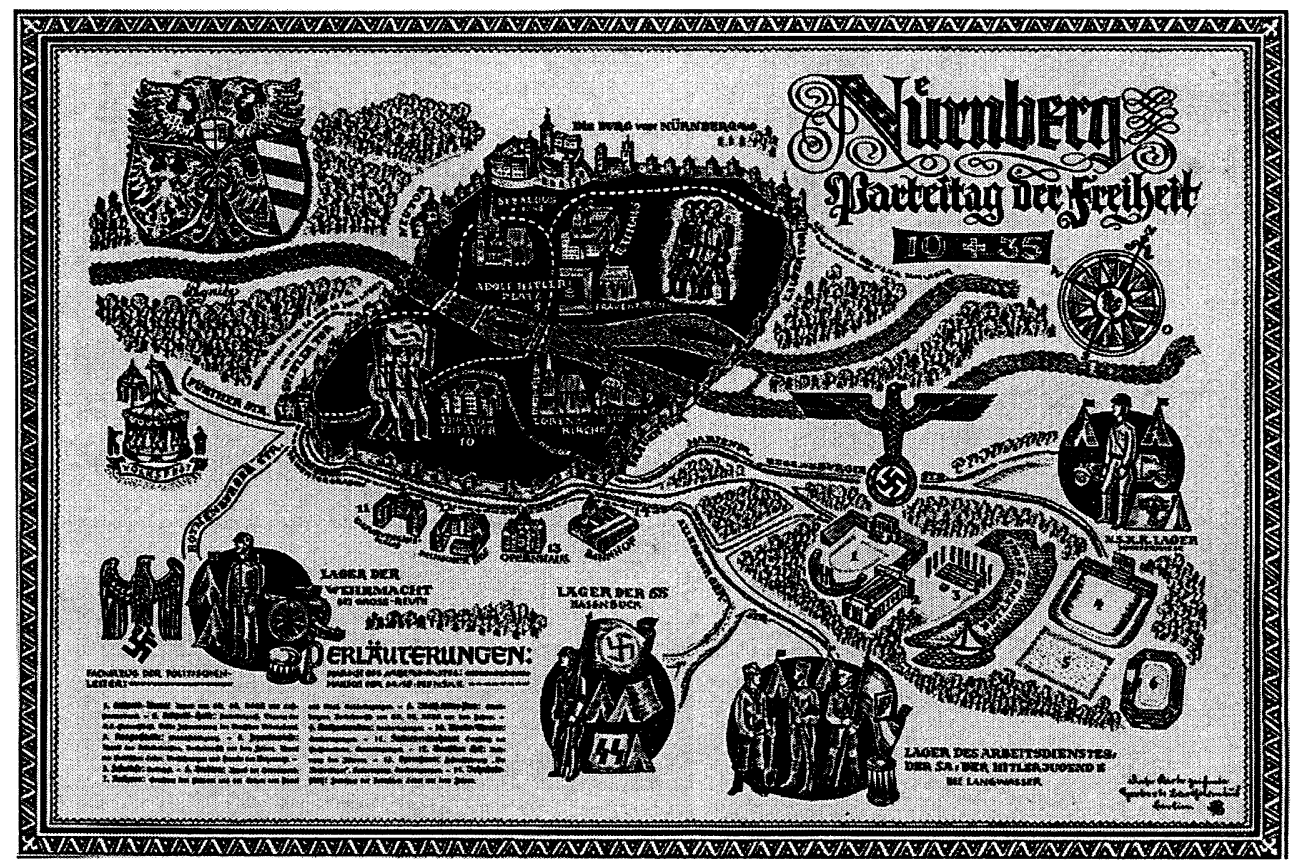

FIGURE 11 The old Nuremberg, seen in black in the upper left, and the new rally grounds, bottom right, are linked by the parade routes of various Nazi Party organizations, depicted by black and white dashed lines on this map from the 1935 rally yearbook. (Courtesy Bayerische Staatsbibliothek München.)

that would overwhelm and envelop participant and observer alike with monumental architecture and massive spectacles. The Zeppelin Field, the Congress Hall and the other structures planned for the rally grounds, Adolph-Hitler-platz, or even the entirety of old Nuremberg surrounded within its medieval fortifications all offered large enclosed spaces. Unlike most monuments, rally venues tended to be things that both participant and observer had to enter and stand within, thereby obscuring the difference between the two. If we continue with the metaphor of landscape as stage, and emphasize the performative nature of place and architecture, the spatial and architectural design of the Nuremberg rallies created a spectacle where everybody was in a sense on stage.

While most other scholars have likened the buildings associated with the rallies to theatre scenery on a massive scale, we argue that the design and staging of the Nuremberg rallies differed significantly from most other political spectacles. Instead of providing a mere scenic backdrop for rally activities, these monuments and spaces projected Nazi aspirations for historical legitimacy and simultaneously signified the party's promise of a grand future. Indeed, in addition to blurring the distinction between participant and observer, the Nazi building programme in Nuremberg also sought to merge past and present. The Nuremberg Party Rallies suggested this historical 
trajectory to hundreds of thousands of participants and to untold millions who experienced the rallies indirectly through film or other means. As a 1938 issue of Die neue Linie explained: 'From the first Imperial Diets, that took place in the thirteenth century, to the Party Rallies, the destiny of the city resolutely followed this mission like a pre-planned parade route. ${ }^{64}$ This calculated utilization of architecture, spectacle and place helped link the 'old' and the 'new' Nuremberg to project and legitimize a Nazi vision of past, present and future.

\section{Notes}

${ }^{1}$ A. Kosfeld, 'Nürnberg', in E. François and H. Schulze, eds, Deutsche Erinnerungsorte (Munich, Beck, 2001), p. 83 (emphasis original). See also B. Rusinek, 'Die deutscheste aller deutschen Städte: Nürnberg als eine Hauptstadt des Nationalsozialismus', in B.-M. Baumunck and G. Brunn, eds, Hauptstadt: Zentren, Residenzen, Metropolen in der deutschen Geschichte (Cologne, DuMont, 1989), pp. 92-98.

${ }^{2}$ S. Daniels and D. Cosgrove, eds, The iconography of landscape: essays on the symbolic representation, design and use of past environments (Cambridge, Cambridge University Press, 1988); J. Duncan and N. Duncan, '(Re)reading the landscape', Environment and planning D: society and space 6 (1988), pp. 117-26; J. Duncan, The city as text: The politics of landscape interpretation in the Kandyan Kingdom (Cambridge, Cambridge University Press, 1990); T. Barnes and J. Duncan, eds, Writing worlds: discourse, text and metaphor in the representation of landscape (London, Routledge, 1992); S. Daniels and D. Cosgrove, 'Spectacle and text: landscape metaphors in cultural geography', in J. Duncan and D. Ley, eds, Place/culture/ representation (London, Routledge, 1993); L. Kong and B.S.A. Yeoh, 'The construction of national identity through the production of ritual and spectacle: an analysis of National Day parades in Singapore', Political geography 16 (1997), pp. 213-39; D. Atkinson and D. Cosgrove, 'Urban rhetoric and embodied identities: city, nation, and empire at the Vittorio Emanuele II monument in Rome, 1870-1945', Annals of the Association of American Geographers 88 (1998), pp. 28-49.

3 F. Driver and D. Gilbert, 'Heart of empire? Landscape, space and performance in imperial London', Environment and planning D: society and space 16 (1998), pp. 11-28; D. Ryan, 'Staging the imperial city: the Pageant of London, 1911', in F. Driver and D. Gilbert, eds, Imperial cities: landscape, display and identity (Manchester, Manchester University Press, 1999); K. Till, 'Staging the past: landscape design, cultural identity and Erinnerungspolitik at Berlin's Neue Wache', Ecumene 6 (1999), pp. 251-83; L. Lees, 'Towards a critical geography of architecture: the case of an ersatz Colosseum', Ecumene 8 (2001), pp. 51-86; S. Hoelscher, 'Making place, making race: performances of whiteness in the Jim Crow South', Annals of the Association of American Geographers 93 (2003), pp. 657-86; J. Hagen, 'The most German of towns: creating an ideal Nazi community in Rothenburg ob der Tauber', Annals of the Association of American Geographers 94 (2004), pp. 207-27.

${ }^{4} \mathrm{~N}$. Johnson, Ireland, the Great War and the geography of remembrance (Cambridge, Cambridge University Press, 2003), p. 10.

${ }^{5}$ H.-U. Thamer, 'The orchestration of the national community: the Nuremberg Party Rallies of the NSDAP', in G. Berghahn, ed., Fascism and theatre: comparative studies on the aesthetics and politics of performance in Europe, 1925-1945 (Providence, RI, Berghahn Books, 1996), p. 172 . 
${ }^{6}$ A. Hitler, Mein Kampf, trans. R. Manheim (Boston, Houghton Mifflin, 1971), p. 266.

7 B. M. Lane, Architecture and politics in Germany, 1918-1945 (Cambridge, MA, Harvard University Press, 1968), pp. 187-89.

${ }^{8}$ Hitler made the final decision at a meeting in Bayreuth, but only after insisting that the Nuremberg city council agree to stipulations that the city place no restrictions on how the grounds would be laid out. Nuremberg mayor Willy Liebel convinced the council to accept Hitler's stipulations and so win approval for Nuremberg as the official rally site. See S. Zelnhefer, Die Reichsparteitage der NSDAP in Nürnberg (Nuremberg, Verlag Nürnberger Presse, 2002), pp. 63-65.

9 The rallies of the 1920s lasted only a few days and lacked the grand edifices and stage work associated with the more elaborately developed, week-long programmes instituted after 1933. See H. T. Burden, The Nuremberg Party Rallies: 1923-1939 (New York; Praeger, 1967) for a comparative accounting of the individual rally programmes.

${ }^{10}$ For a detailed accounting of the content of the daily programme as it was established in 1933, see Zelnhefer, Reichsparteitage, pp. 95-113.

11 A. Schmidt, Geländebegebung: Das Reichsparteitagsgelände in Nürnberg (Nuremberg, Geschichte für Alle, 2002), pp. 160-63.

12 Zelnhefer, Reichsparteitage, pp. 84-85.

${ }^{13}$ A voluminous literature describes the various sites and facilities that made up the rally grounds. Informative and up-to-date descriptions may be found in Schmidt, Geländebegebung; Y. Doosry, 'Woblauf, laßt uns eine Stadt und einen Turm bauen ...'S Studien zum Reichsparteitagsgelände in Nürnberg (Tübingen, Wasmuth, 2002); and in E. Dietzfelbinger and G. Liedtke, Nürnberg - Ort der Massen. Das Reichsparteitagsgelände Vorgeschichte und schwieriges Erbe (Berlin, Links, 2004). The text from the official 1938 guide to the grounds, replete with detailed dimensions and descriptions of all the major facilities, may be found in $\mathrm{J}$. Dülfer, J. Thies and J. Henke, Hitlers Städte: Baupolitik im Dritten Reich. Eine Dokumentation (Cologne, Böhlau, 1978).

${ }^{14}$ H. Bernett, 'Zur Grundsteinlegung vor 50 Jahren: Das "Deutsche Stadion" in Nürnberg - ein Phantom nationalsozialistischen Größenwahns', Sozial- und Zeitgeschichte des Sports 1 (1987), pp. 14-39; A. Scobie, Hitler's state architecture: the impact of classical antiquity (University Park, PA, College Art Association, 1990), pp. 75-80; P. Jaskot, The architecture of oppression: the SS, forced labour and the Nazi building economy (London, Routledge, 2000), pp. 60-61.

$15 \mathrm{H}$. Hoffman, The triumph of propaganda: film and National Socialism, 1933-1945 (Providence, RI, Berghahn Books, 1996), pp. 152-53; Thamer, 'The orchestration of the national community', pp. 172-76.

${ }^{16}$ Ibid., pp. 181-82; Zelnhefer, Reichsparteitage, p. 246.

17 This sequence in the film Triumph of the will (1935), which runs for a little over 8 minutes, is one of the film's most memorable and powerful scenes.

${ }^{18}$ F. Spotts, Hitler and the power of aesthetics (Woodstock, NY, Overlook Press, 2003), pp. 5960.

19 Zelnhefer, Reichsparteitage, pp 77-79.

${ }^{20}$ Y. Karow, Deutsches Opfer: Kultische Selbstauslöschung auf den Reichsparteitagen der NSDAP (Berlin, Akademie, 1997), p. 40.

${ }^{21}$ Lane, Architecture and politics in Germany, pp. 189-90; see also Spotts, Hitler and the power of aesthetics, pp. 330-35.

${ }^{22}$ Scobie, Hitler's state architecture, p. 69.

${ }^{23}$ Lane, Architecture and politics in Germany, pp. 190-91. 
${ }^{24}$ See Jascot, The architecture of oppression, p. 53; Scobie, Hitler's state architecture, pp. 87, 77.

25 Ibid., pp. 80-85.

${ }^{26}$ Lane, Architecture and politics in Germany, p. 193; L.-O. Larsson, 'Classicism in the architecture of the XXth century', in L Krier, ed., Albert Speer Architecture, 1932-1942 (Brussels, Aux Archives D'Architecture Moderne, 1985), pp. 233-45.

27 A. Speer, Inside the Third Reich (New York, Macmillan, 1970), pp. 56-57.

28 Jaskot, The architecture of oppression, pp. 61-67.

29 Quoted in Karow, Deutsches Opfer, p. 51.

30 W. Lotz, 'Ein Denkmal des Stolzes: Die Bauten auf dem Reichsparteitagsgelände in Nürnberg', Die Kunst im deutschen Reich 1 (1937), pp. 76-88.

${ }^{31}$ U. von Petz, Stadtsanierung im Dritten Reich: Dargestellt an ausgewäblten Beispielen (Dortmund, IRPUD, 1987); W. Speitkamp, 'Denkmalpflege und Heimatschutz in Deutschland zwischen Kulturkritik und Nationalsozialismus', Archiv für Kulturgeschichte 70 (1988), pp. 149-93; U. von Petz, 'Urban renewal under National Socialism: practical policy and political objectives in Hitler's Germany', Planning perspectives 5 (1990), pp. 169-87; R. Koshar, 'Altar, stage and city: historic preservation and urban meaning in Nazi Germany', History and Memory 3 (1991), pp. 30-59; T. Scheck, Denkmalpflege und Diktatur: Die Erhaltung von Bauund Kunstdenkmälern in Schleswig-Holstein und im Deutsche Reich zur Zeit des Nationalsozialismus (Berlin, Verlag für Bauwesen, 1995); R. Koshar, Germany's transient pasts: preservation and national memory in the twentieth century (Chapel Hill, University of North Carolina Press, 1998); Hagen, 'The most German of towns'.

32 J. Lincke, 'Die Wiederinstandsetzung der Nürnberger Kaiserburg im Jahre 1934', Der Burgwart 36 (1935), pp. 12-19.

33 W. Brugmann, 'Bausünden in Alt-Nürnberg', Das Bayerland 45 (1934), pp. 218-23; Berlitz, 'Baupflege in deutschen Städten', Zentralblatt der Bauverwaltung 57 (1937), pp. 1033-35.

${ }^{34}$ W. Liebel, 'Zum Geleit', Nürnberg: Die Stadt der Reichsparteitage, special issue of Das Bayerland 46 (1935), p. 1.

35 Die Erneuerung der Altstadt in Nürnberg, ed. Oberbürgermeister der Stadt der Reichsparteitage Nürnberg, vol. 3 (Nuremberg, Volkhardt \& Wilbert, 1937), p. 7.

${ }^{36}$ H. Höhn, 'Umgestaltungen in der Altstadt von Nürnberg', Deutsche Kunst und Denkmalpflege 4 (1934), p. 73.

37 Brugmann, 'Bausünden in Alt-Nürnberg'; Höhn 'Umgestaltungen in der Altstadt von Nürnberg'; Berlitz, 'Baupflege in deutschen Städten'.

38 Die Erneuerung der Altstadt in Nürnberg (1937), pp. 9-10.

39 Lincke, 'Die Wiederinstandsetzung der Nürnberger Kaiserburg', pp. 12, 19.

${ }^{40} \mathrm{H}$. Höhn, 'Die Wiederherstellung der Kaiserburg in Nürnberg', Deutsche Kunst und Denkmalpflege 5 (1935), p. 25.

41 Die Erneuerung der Altstadt in Nürnberg, ed. Oberbürgermeister der Stadt der Reichsparteitage Nürnberg, vol. 4 (Nuremberg, Volkhardt \& Wilbert, 1941), p. 36.

${ }^{42}$ Höhn, 'Umgestaltungen in der Altstadt von Nürnberg', pp. 76-77; Die Erneuerung der Altstadt in Nürnberg, vol. 3, pp. 41-49.

43 Ibid., vols. 3 and 4; J. Lincke, 'Erneurungsarbeiten am Heilig-Geist-Spital in Nürnberg', Zentralblatt der Bauverwaltung 60 (1940), pp. 705-12.

44 Die Erneuerung der Altstadt in Nürnberg, vol. 4, p. 72.

${ }^{45}$ Ibid., pp. 65-81.

46 Brugmann, 'Bausünden in Alt-Nürnberg', p. 221. Brugmann does not specify what exactly is 'Moorish' about the synagogue, but is probably referring to its historicized entrance, which featured columns reminiscent of Arabic Spain, or possibly its large domed roof. 
${ }^{47}$ Quoted in A. Schmidt, 'Saubere Altstadt: "Entschadelung” und Zerstörung der Nürnberger Altstadt im Nationalsozialismus', in H. Beer et. al., eds, Bauen in Nürnberg 1933-1945: Architektur und Bauformen im Nationalsozialismus (Nuremberg, Tümmels, 1995), p. 142.

${ }^{48}$ F. Kriegbaum, Nürnberg, 2nd edn (Berlin, Deutscher Kunstverlag, 1939), p. 9.

49 W. Brugmann, 'Die Bauten des Reichsparteitage', Nürnberg: Die Stadt der Reichsparteitage, special issue of Das Bayerland 46 (1935), p. 96.

50 Guide: The Buildings of the Party Rally Grounds in the Town of the Party Rallies Nuremberg (Nuremberg, Zweckverband Reichsparteitag Nürnberg, 1937).

51 F. Bock, Nürnberg: Von der Stadt der Reichstage zur Stadt der Reichsparteitage. (Stuttgart, Franck, 1938), p. 60.

52 Ibid., p. 61.

${ }^{53}$ Most of the crown jewels had been stored in Nuremberg from 1424 to 1792 . During the Napoleonic wars they were moved for safekeeping to Vienna, where they remained until 1938. R. Endres, 'Carissima civitas: Kaiserstadt und Aufbewahrungsort der Reichsinsignien', in Baumunck and Brunn, Hauptstadt, pp. 72-87.

${ }^{54}$ C. Sabo, Die Stadt der Parteitage Nürnberg (Berlin, K.G., 1938).

55 Ibid.

56 G. Schwemmer, Nürnberg: Das Bild einer politischen Stadt (Potsdam, Ludwig Voggenreiter, 1937), p. 80.

57 W. Dittschlag, Nürnberg: Die Stadt der Reichsparteitage (Düsseldorf, August Bagel, 1937), p. 10.

58 Ibid., p. 97.

59 Schwemmer, Nürnberg, p. 80.

${ }^{60}$ E.g. E. Eichhorn, 'Kaiserort and Führerstadt: Die imperiale Tradition Nürnbergs und ihre Bedeutung für die Reichsparteitagsgelände', in Centrum Industriekultur, eds, Kulissen der Gewalt: Das Reichspartietagsgelände in Nürnberg (Munich, Hugendubel, 1992), pp. 13-18; Zelnhefer's Die Reichsparteitage der NSDAP, which provides an incredibly detailed look at the rallies but only devotes 6 pages to the redesign of old Nuremberg; while Doosry's lengthy Woblauf, laßt uns eine Stadt und einen Turm bauen ... ignores the importance of old Nuremberg as a rally venue.

${ }^{61}$ Illustrierte Fübrer durch Nürnberg und Umgebung, 35th edn (Leipzig, Woerl's Reisehandbücher, 1939), p. 15.

${ }^{62}$ Kong and Yeoh, 'The construction of national identity', 216 (emphasis added).

63 See D. Harvey, 'Monument and myth', Annals of the Association of American Geographers 69 (1979), pp. 362-81; N. Johnson, 'Cast in stone: monuments, geography and nationalism', Society and space 13 (1995), pp. 51-66; Atkinson and Cosgrove, 'Urban rhetoric and embodied identities'. On national monuments and festivals in Germany, see G. Mosse, The nationalization of the masses: political symbolism and mass movements in Germany from the Napoleonic Wars through the Third Reich (Ithaca, NY, Cornell University Press, 1975); R. Koshar, From monuments to traces: artifacts of German memory, 1870-1990 (Berkeley, University of California Press, 2000).

${ }^{64}$ Quoted in Zelnhefer, 'Die historische Kulisse', in Centrum Industriekultur, eds, Unterm Hakenkreuz: Alltag in Nürnberg 1933-1945 (Munich, Hugendubel, 1993), p. 40. 